Jurnal Gizi dan Dietetik Indonesia

(Indonesian Journal of Nutrition and Dietetics)

Vol. 8, No. 2, 2020: 54-60
Available online at: http://ejournal.almaata.ac.id/index.php/IJND

DOI : http://dx.doi.org/10.21927/ijnd.2020.8(2).54-60

\title{
The rule of nutrition counseling media to students' snacking behavior
}

\author{
Anto J. Hadi*, Syamsopyan Ishak ${ }^{1}$, Matius Rantesalu²
}

${ }^{1}$ Public Health Department, Public Health Faculty, Universitas Aufa Royhan, Padangsidimpuan, Indonesia

${ }^{2}$ Nutrition Department, Akademi Kebidanan Sinar Kasih Toraja, Tana Toraja, Indonesia

${ }^{*}$ Corresponding author: antoarunraja@gmail.com

\begin{abstract}
Latar Belakang: Banyaknya berbagai jenis jajan saat ini yang beredar tidak aman dikonsumsi anak usia sekolah dasar di lingkungan sekolah maupun dirumah. Makanan jajanan yang ditawarkan penjual belum tentu menyehatkan dan hal yang disukai anak-anak sekolah dasar tetapi sayangnya tidak semuanya aman dikonsumsi oleh anak.

Tujuan : Untuk menilai pengaruh media penyuluhan gizi terhadap perilaku jajan siswa di SD Negeri 107422 Pagar Jati Kabupaten Deli Serdang.

Metode: Penelitian ini adalah quasi experiment dengan desain pretest-posttest group. Penelitian dilaksanakan di SD Negeri 107422 Pagar Jati dan dilakukan pada bulan September dan Oktober 2019. Populasi sebanyak 60 siswa dan sampel terbagi menjadi 2 kelompok dengan jumlah masing-masing sebanyak 30 siswa dan pengambilan sampel secara proportional random sampling. Analisis data dengan menggunakan uji paired sample t-test.

Hasil: Ada pengaruh media penyuluhan gizi terhadap sikap dan tindakan konsumsi makanan jajanan pada siswa sekolah dasar baik dengan menggunakan powerpoint $(p=0,000)$ maupun leaflet $(p=0,000)$. Skor rata-rata sikap dan tindakan siswa meningkat dari pretest ke posttest dan lebih tinggi peningkatannya pada penggunaan media powerpoint.

Kesimpulan: Terdapat pengaruh positif media penyuluhan gizi terhadap sikap dan tindakan siswa dengan perilaku jajan siswa. Bagi siswa diharapkan selalu memilih makanan sehat dan tidak memilih jajanan yang kurang sehat.
\end{abstract}

ABSTRAK

KATA KUNCI: media penyuluhan gizi; perilaku ngemil sehat

\begin{abstract}
Background: Various types of snacks currently existed in the market are not safe for consumption by elementary school-aged children at school or home environment. Snack food offered by the seller is not necessarily healthy yet the children like. But unfortunately there are several snacks that are not safe for children consumption.

Objectives: This study aims to assess the effect of nutrition counseling media on student snack behavior in SD Negeri 107422 Pagar Jati, Deli Serdang Regency.

Methods: This study was a quasi-experimental approach using pretest and post-test group design. The study was conducted at SD Negeri 107422 Pagar Jati, Deli Serdang Regency in September to October 2019. The population were 60 students. Samples were then divided into 2 groups with a total of 30 students using proportional random sampling. Data analysis used was paired sample t-test.

Results: There was an influence of nutrition counseling media on the attitudes and actions of snacking behavior for elementary school students using either powerpoint $(p=0.000)$ or leaflets $(p=0.000)$.

Conclusion: The average score of students'snacking attitudes and actions increases from pretest to post-test and higher increases in the use of powerpoint media. Students are expected to always choose healthy foods and not to choose snacks that are less healthy.
\end{abstract}

KEYWORD: nutrition counseling media; healthy snacking behavior

Article info:

Article submitted on January 16, 2020

Articles revised on February 9, 2020

Articles received on August 7, 2020 


\section{INTRODUCTION}

Problems arisen in the field in primary school age children nutrition is a very important issue in the public health nutrition problem. Nutrition problems in school-age children are often associated with snacking habits both at school and at home.(1) School-age children generally spend a quarter of their daily time at school. With many activities at to follow, children often tend to forget about eating time.(2)particularly on schooled rest hour interval. But consumption wont food healthy still haven't a lot of proprietary by school child. lu00a0 $\mathrm{Ir}$ This research is executed at Inpres Maccini Sombala Elementary School Makassar. Observational type that is utilized is observasional with approaching cross sectional study which is to analysis associated factor alimentary election on student at Inpres Maccini Sombala Elementary School Makassar 2017. This observational sample is Elementary School student with taking sample purphosive sampling lu00a0with amount 146 samples. Ir Acquired observational result that science concerning alimentary election on student with value $p(0,000$ Until now there is still a lot of food and snacks that is being sold at school for children to buy and the snacks do not meet health requirements even in standard healthy parameter. This fact can cause adverse effects on nutrition and health of children such as food poisoning which is so dangerous. In addition, more than 100 students in Medan, namely the North Sumatra Vocational High School in North Sumatra experienced food poisoningin 2017. Unhealthy snacking behavior can cause negative effects such as abdominal pain and diarrhea.(3)

Elementary school age students are very vulnerable to cases of food poisoning caused by the children's intention to eat unhealthy snacks at and around their schools. Nutrition knowledge is also very influential on attitudes and behaviors in choosing food, especially in choosing the right, rich in nutrition, and balanced foods or snacks. It also provides the basis for good and right nutritional behavior that concerns a person's eating habits.(4)

Promotion to eat healthy food is one effective way that can be done to limit school children in consuming unhealthy snacks as children's behavior. The leaflet media can be used because it is more effective in conveying nutrition information and education.(5)

Pilot study done through preliminary survey results show that some snacks sold by traders or sellers around SD Negeri 107422 are very strong and striking in colorwhich is suspected to use dyes. Some foods are chewy which is considered using preservatives ingredients. Those are harmful to health badly. Some other foods also taste too sweet which are used sweeteners as condiments. Types of snacks that are sold in elementary schools are meatballs, rolled eggs, fried noodles, and flavored snacks such as chiki, chitato, and others. It also sells drinks such as ice popsicles and ice cream using sugar juice, as well as bottled drinks such as the beverages in the glass and others. Some of these snacks can pose a risk of food poisoning or damage to the digestive system if they are consumed in excess due to the ignorance of the elementary school students whether the snacks are safe and healthy for consumption or not. According to the school members, they stated that the school had never received counseling from health workers about healthy snacks. Based on this background, this study aims to assess the rule of nutrition counseling media to student' snacking behavior at SD Negeri 107422 Pagar Jati, Deli Serdang Regency.

\section{MATERIALS AND METHODS}

The research approach used in this study was quasi-experimental method with a pretest and post-test group design. This study was conducted at SD Negeri 107422 Pagar Jati, Deli Serdang Regency. For two months, this study was conducted during September to October 2019. The population and sample was 60 students and the sample was divided into 2 groups with 30 students each and the sampling was proportional random sampling. Interventions conducted with educator of nutrition counseling were given to group I using powerpoint and group II using leaflets modification of Depkes. The data used are primary and secondary data. Data 
were taken before nutrition counseling (pretest) and after nutrition counseling media treatment (posttest). Data analysis used was the $t$ test (paired sample $t$ test) with a confidence level of $95 \%$ ( $p$ $=0.05$ ) and food frequency questionare (FFQ). Ethical approval has been obtained from Ethical Commission of Health Research, Faculty of Public Health, with protocol number UH910183001.

\section{RESULTS}

Table 1. Respondent' DistributionBased onCharacteristicsat SD Negeri 107422 Pagar Jati, Deli Serdang Regency

\begin{tabular}{lrrrr}
\hline \multirow{2}{*}{ Characteristics } & \multicolumn{2}{c}{$\begin{array}{c}\text { Group I } \\
\text { (Powerpoint) }\end{array}$} & \multicolumn{2}{c}{$\begin{array}{c}\text { Group II } \\
\text { (Leaflet) }\end{array}$} \\
\cline { 2 - 5 } & $\mathbf{n = 3 0}$ & \multicolumn{1}{c}{$\%$} & $\mathbf{n = 3 0}$ & \multicolumn{1}{c}{$\%$} \\
\hline Age: & & & & \\
10 years & 13 & 43.4 & 10 & 33.3 \\
11 years & 16 & 53.3 & 18 & 60.0 \\
12 years & 1 & 3.3 & 2 & 6.7 \\
Gender: & & & & \\
Male & 19 & 63.3 & 21 & 70.0 \\
Female & 11 & 36.7 & 9 & 30.0 \\
Religion: & & & & \\
Islam & 25 & 83.3 & 20 & 66.7 \\
Christian & 5 & 16.7 & 9 & 30.0 \\
Catholic & 0 & 0.0 & 1 & 3.3 \\
Ethnic Group: & & & & \\
Batak & 10 & 33.3 & 13 & 43.4 \\
Javanese & 13 & 43.4 & 9 & 30.0 \\
Malay & 6 & 20.0 & 1 & 3.3 \\
Karo & 0 & 0.0 & 1 & 3.3 \\
Aceh & 0 & 0.0 & 1 & 3.3 \\
Nias & 0 & 0.0 & 1 & 3.3 \\
Padang/Minang & 1 & 3.3 & 0 & 0.0 \\
Mandailing & 0 & 0.0 & 4 & 13.4 \\
\hline
\end{tabular}

Table 1 shows that the majority of group I respondents aged 11 years were $53.3 \%$, while group II respondents aged 11 years were $60.0 \%$. Based on gender, the majority of group I and group II respondents was male with the number of $63.3 \%$ and group II was male with the number of $70.0 \%$. Based on religion, the majority of group I respondents were Muslims as much as $83.3 \%$, likewise group II respondents were Muslim as much as $66.7 \%$. Based on ethnicity, the majority of group I respondents were Javanese as much as $43.4 \%$, while group II respondents were mostly Batak as much as $43.4 \%$.
Table 2. Distribution of Students' Snacking Behavior Before Treatment (Pretest)at SD Negeri 107422 Pagar Jati, Deli Serdang Regency

\begin{tabular}{ccccc}
\hline $\begin{array}{c}\text { Snacking } \\
\text { behavior } \\
\text { (Pretest) }\end{array}$ & \multicolumn{2}{c}{$\begin{array}{c}\text { Group I } \\
\text { (Powerpoint) }\end{array}$} & \multicolumn{2}{c}{$\begin{array}{c}\text { Group II } \\
\text { (Leaflet) }\end{array}$} \\
\cline { 2 - 5 } & $\mathbf{n}$ & $\%$ & $\mathbf{n}$ & $\%$ \\
\hline $\begin{array}{c}\text { Attitudes } \\
\text { Good }\end{array}$ & 15 & 50.0 & 18 & 60.0 \\
Less & 15 & 50.0 & 12 & 40.0 \\
Actions & & & & \\
Good & 16 & 53.3 & 16 & 53.3 \\
Less & 14 & 46.7 & 14 & 46.7 \\
\hline
\end{tabular}

Table 2 shows that the attitudes and actions of students in group I and group II about healthy snacks at school before being counseled using powerpoint and leaflets media as treatments (pretest).It is showed that group I respondents who behaved good as those who behaved less were $50.0 \%$. The attitudes of group II respondents were mostly good and it is showed by the number of respondents which are $60.0 \%$ while a small proportion or respondents were less and it is showed by the number of $40.0 \%$. Whereas the actions of group I and group II students about healthy snacks at school before being counseled using powerpoint and leaflets media (pretest) showed that most of the actions of group I respondents are in the good category (53.3\%) while a small proportion were in the less category ( $46.7 \%)$. The actions of group II respondents also showed the same thing that most of respondent were in the good category $(53.3 \%)$ while a small proportion were in the less category $(46.7 \%)$. Both actions in group I and group II were the same.

Table 3. Distribution of Students' Snacking Behavior After Treatment (Post-test)at SD Negeri 107422 Pagar Jati, Deli Serdang Regency

\begin{tabular}{ccccc}
\hline $\begin{array}{c}\text { Snacking } \\
\text { behavior } \\
\text { (Post-test) }\end{array}$ & \multicolumn{2}{c}{$\begin{array}{c}\text { Group I } \\
\text { (Powerpoint) }\end{array}$} & \multicolumn{2}{c}{$\begin{array}{c}\text { Group II } \\
\text { (Leaflet) }\end{array}$} \\
\cline { 2 - 5 } Attitudes & $\mathbf{n}$ & $\%$ & $\mathbf{n}$ & $\%$ \\
Good & 28 & 93.3 & 25 & 83.3 \\
Less & 2 & 6.7 & 5 & 16.7 \\
Actions & & & & \\
Good & 26 & 86.7 & 20 & 66.7 \\
Less & 4 & 13.3 & 10 & 33.3 \\
\hline
\end{tabular}

Table 3 shows that the attitudes and actions of group I and group II students about healthy snacks 
at school after being counseled using powerpoint and leaflets media(post-test).It is showed that the majority of group I respondents were good as much as $93.3 \%$ while a small proportion were less as much as $6.7 \%$. Most of the respondents in group II have had good attitude with the number of $83.3 \%$ while a small proportion have had less attitudewith the number of $16.7 \%$. Thus the actions of group I and group II students on healthy snacks at school after being counseled using powerpoint and leaflets media(post-test) showed that most of the actions of group I respondents were in the good category $(86.7 \%)$ while a small proportion were in the less category (13.3\%). The actions of group II respondents also showed the same thing that most respondent were in the good category $(66.7 \%)$ while a small proportion were in the less category (33.3\%).

Table 4. The Rule of Nutrition Counseling Media to Students'Snacking Behavior at SD Negeri 107422 Pagar Jati, Deli Serdang Regency

\begin{tabular}{lcccc}
\hline \multirow{2}{*}{$\begin{array}{c}\text { Snacking } \\
\text { behavior }\end{array}$} & \multicolumn{2}{c}{$\begin{array}{c}\text { Groupl } \\
\text { (Powerpoint) }\end{array}$} & \multicolumn{2}{c}{ Group II (Leaflet) } \\
\cline { 2 - 5 } & Pretest & Post-test & Pretest & Post-test \\
\hline Attitudes & & & & \\
Mean & 35.10 & 40.17 & 34.50 & 38.40 \\
Deviation & & & & \\
Standard & 3.155 & 2.588 & 3.224 & 3.136 \\
t-count it & -8.059 & & -11.698 & \\
$p$-value & 0.000 & & 0.000 & \\
Actions & & & & \\
Mean & 11.87 & 13.730 & 11.60 & 12.73 \\
$\begin{array}{l}\text { Deviation } \\
\text { Standard }\end{array}$ & 2.080 & 1.507 & 2.061 & 1.837 \\
t-count it & -5.413 & & & -3.750 \\
p-value & 0.000 & & & 0.001 \\
\hline
\end{tabular}

Table 4 shows that the attitudes on the $\mathrm{t}$-count value in group I $(-8.059)<\mathrm{t}$-table $(2.045)$ and significant value $(0.000<0.05)$ then there is a significant (difference) influence of students' attitudes about healthy snacks before being counseled nutrition using powerpoint media (pretest) with the attitude after being counseled using powerpoint media (post-test). Likewise, the value of $t$-count in group II $(-11,698)<t$-table $(2.045)$ and significant value $(0.000<0.05)$ then there is a significant (difference) effect of students' attitudes about healthy snacks before being counseled using leaflets media (pretest) with attitudes after being counseled using leaflets media (post-test). Likewise, the value of t-count in group II (-3.750) <t-table (2.045) and significant value $(0.001<0.05)$ then there is a significant (difference) effect of students' actions about healthy snacks before being given nutrition counseling using leaflets media (pretest) with action after being given counseling using leaflets media (post-test).

\section{DISCUSSION}

Based on the results of the study, it is showed that there was a significant influence (difference) in the attitudes of students in group I about healthy snacks before being counseled using powerpoint (pretest) with attitudes after being counseled using powerpoint (post-test) as treatment. Likewise in group II there was a significant influence (difference) of students' attitudes about healthy snacks before being counseled using leaflets media (pretest) with attitudes after being counseled using leaflets media (post-test). Research conducted by Keumalasari in MIN Lamrabo, Kutabaro District, Aceh Besar District in 2017 with health promotion was using lecture, discussion, demonstration and games using leaflets, booklets and powerpoint as interventions or treatments. The results showed that there was an effect of health promotion on improving attitudes with a mean value of 47.74 before the intervention increased to $64.47(p=0.000)(p=0.000)$. (6) The study was supported by Manurung research in the Village of Ramunia-I, Pantai Labu Sub-District, Deli Serdang Regency. It showed that the attitude of the students' mother before nutrition counseling was sufficient while after the nutrition counseling, the attitude of the students' mother became good. It proves that counseling with powerpoint is effective in changing attitudes of the target.(7) Besides knowledge, an important component that can rule adolescent behavior in food selection is attitude. Attitude is the reaction or response of someone who is still closed to a stimulus or object. Attitudes will be very useful for someone, because attitudes will direct behavior spontaneously. Attitudes consist of 
positive attitudes and negative attitudes. A positive attitude will foster positive behavior and vice versanegative attitude will foster negative behavior, such as rejecting, avoiding, leaving, even to things that has damage to someone's health. A positive attitude towards adolescents towards health might not directly affect adolescent behavior, but a negative attitude toward health almost certainly affects their behavior because attitude is a readiness to act toward something encountered to our body. Attitudes can change if you get counseling or health education.(8)

The selection and the use of media is an important component in providing health education and promoting nutrition in foods and beverages. In carrying out promotional activities for school children, it is better to use the content and format of educational materials that are suitable to the needs of students themselves. Questions in the questionnaire are also adjusted to the intellectual level of students, so that after gaining knowledge, students can have positive attitudes.(8) According to the researchers'assumptions, nutritional counseling is effective and is able to rule students' attitudes about healthy snacks such as counseling using powerpoint or leaflets media. The attitude of students becomes more positive after being given education or health education than before being given health education. The two counseling media are able to change students' perceptions of healthy snacks from negative attitudes to positive attitudes. Based on the average attitude score in group I (powerpoint), the score was 35.10 in the pretest and it has increased to 40.17 in the posttest. The increase score was 5.07 points. Likewise in group II (leaflets) there was an increase in attitudes score from 34.50 in the pretest to 38.40 in the post-test. The increase score was 3.90 points. It proves that the increase in scores in group I (powerpoint) is higher than in group II (leaflets). In addition to the media used, the students'own factors also play a role in increasing scores, such as students' readiness to attend counseling, student memory, and others.

Health promotion such as nutrition counseling at schools and other academic institutions is a top priority and is one of the effective interventions that increases student awareness of the importance of choosing healthy snacks at schools and surroundings(9). It is expected that health education such as nutrition counseling about healthy snacks can be used as one of the health measurement for students at schools. Research conducted by Wowor et.al found the fact that children who were educated in consuming skills were better and healthier than children who were not educated.(10) Amalia et.al stated that increasing the amount of information in children would improve the structure of knowledge development of children older than 9 years.(11) Bogor District. The design used as survey method at three elementary schools at the area, namely SDN 01 Palasari, SDN 02 Palasari, dan SDN 01 Cipicung. The data was collected in April until June 2012. The subjects of study were 80 students at 4 th and 5th grade of elementary school, consisted of 40 boys and 40 girls. Data collection was done by observation and interview to students. The data collected were: family characteristics, individual characteristics, nutrition knowledge, preference and the reasons, and consumption frequency of the street foods. The results showed that family size of subjects mostly $(65.5 \%$ Based on the results of the study showed that there was a significant influence (difference) in the actions of group I students regarding healthy snacks before being counseled using powerpoint media (pretest) with actions after being counseled using powerpoint media (posttest). Likewise in group II there was a significant influence (difference) of students' actions on healthy snacks before being counseled using leaflets media (pretest) with actions after being counseled using leaflets media (postitest). The difference was significant enough to see between the results.

This research is supported by the research conducted by Tampubolon in SMA 1 Panyabungan, Mandailing Natal Regency, which had pointed the study at the effect of nutrition counseling with leaflets media about healthy food on the students' snacking behavior. The results showed that nutrition counseling with leaflets media was able to increase the actions of consuming healthy snacks for secondary school students.(12) According to 
the researchers' assumptions, nutrition counseling has been given to students in the two elementary schools. The results of this study was effective in changing the actions of students who pretested the actions in the less category. After the pretest held, the actions of students become good. In this study, the healthy snacks provided were the same as those between powerpoint and leaflets in understanding of healthy snacks, the function of snacks for school children, types of snacks, snacks, the impact of unhealthy snacks, how to choose healthy snacks, and prevention of careless snacks. The actions examined in this study are related to breakfast routines at home, washing hands before eating snacks, giving snacks at school canteens, buying packaged food, bringing drinking water from home, and buying snacks that are clean, tasty and nutritious. Extension media other than powerpoint that are often used for counseling or health education are leaflets. Leaflets are a medium used in health promotion practices because leaflets can convey information with words and images that can motivate elementary students to change their behavior from choosing unhealthy snacks to unhealthy snacks. Factors affecting children's nutritional problems are unhealthy snacking behavior. Snacks are an inseparable part of human life. Food snacks are expected in addition to low prices and diverse types, also contribute quite important contributions to nutritional needs. School children love snack food.(13)thus need nutritions with goodlu00a0and proper quality and quantity. Nutrient needs can be fulfilled through eating habits. Snacking habit canlu00a0also contribute to nutritional status in children if the snack consumed has good quality in term of the type $</$ em $><$ br $\mid><$ em $>$ and quantity. $<1$ em $><$ p $><$ p $><$ em $><$ strong $>$ Objectives $</$ strong $>$ : To understand the relationship between snacking habit and diet with nutritional status oflu00a0elementary school children in SD Sonosewu Bantul Yogyakarta. $<1$ em $><$ p $><$ p $><$ em $><$ strong $>$ Methods $<$ /strong $>$ : This study was an observational research with cross sectional approach. This study populationl u00a0was all students in SD Sonosewu Bantul Yogyakarta grades III, IV, V, that were 160 respondents. Thelu00a0sample used in this study was 65 people selected by using simple random sampling. The process of $</ e m><b r$ $1><$ em $>$ selecting a random sample was based on the random number table. The research instruments used werelu00a0questionnaires, form of 24 -hour food recall for 1 day, bathroom scales, and microtoise. The collectedlu00a0data was analyzed by using a statistical test chi-square. $<1$ em $></$ p $><$ p $><$ br $/><$ em $><$ strong $>$ Results $</$ strong $>$ : Respondents who had frequent snacking habit with a normal nutritional status was 27 respondents। u00a0 $81 \%$ Traders strive to give children an attractive appearance and taste by adding certain ingredients without regard to safety(14).

\section{CONCLUSION AND RECOMMENDATION}

Based on the research results and discussion, it can be concluded that there was an influence of nutrition counseling media (power point and leaflets) as the rule effect on attitudes and actions of students' snacking behavior. For students who have negative attitudes and actions, it is necessary to increase knowledge related to the behavior of consuming healthy snacks and efforts to promote health by involving parents and teachers.

\section{CONFLICT OF INTEREST:}

The author (s) declare that they have no conflict interest

\section{REFERENCES}

1. Hadi AJ, Manggabarani S, Said I. Tatalaksana Pola Konsumsi Terhadap Status Gizi Anak Taman Kanak-Kanak. MPPKI (Media Publ Promosi Kesehat Indones Indones J Heal Promot [Internet]. 2019 Feb 6 [cited 2020 Sep 18];2(1):12-20. Available from: https://doi. org/10.31934/mppki

2. Hatta $H$, J. Hadi A, Yetti R E, Tombeg Z, Manggabarani $S$. The Relationship Between Food Selection Factors For Students at Maccini Sombala Inpres Elementary School Makassar City. Wind Heal J Kesehat [Internet]. 2018 Oct 
25 [cited 2020 Sep 18];355-63. Available from: http://jurnal.fkmumi.ac.id/index.php/woh/article/ view/woh1406

3. Khomsan A. Sehat dengan Makanan Berkhasiat. Suhanda I, editor. Jakarta: Penerbit Buku Kompas; 2016.

4. Vio F, Salinas J, Montenegro E, González CG, Lera L. Impact of a nutrition education intervention in teachers, preschool and basic school-age children in Valparaiso region in Chile. Nutr Hosp. 2014;29(6):1298-304.

5. Lucie S. Teknik Penyuluhan dan Pemberdayaan Masyarakat. Cetakan 2. Jakarta: Ghalia Indonesia; 2015.

6. Keumalasari, Hasballah K, Imran. Promosi Kesehatan Cuci Tangan dan Jajanan Sehat Terhadap Pengetahuan dan Sikap Siswa. J IImu Keperawatan. 2017;5(1):1-11.

7. Manurung SST. Pengaruh Penyuluhan Gizi terhadap Perilaku Ibu dalam Penyediaan Menu Seimbang untuk Balita di Desa Ramunia-I Kecamatan Pantai Labu Kabupaten Deli Serdang Tahun 2010. Universitas Sumatera Utara; 2010.

8. Notoatmodjo S. Promosi kesehatan dan Perilaku Kesehatan. Cetakan II. Jakarta: Rineka Cipta; 2016.

9. Wouters EJ, Larsen JK, Kremers SP, Dagnelie PC, Geenen R. Peer influence on snacking behavior in adolescence. Appetite [Internet]. 2010 [cited 2020 Sep 28];55(1):11-7. Available from: https://pubmed.ncbi.nlm.nih. gov/20211671/
10. Wowor P, Engkeng S, Kalesaran AFC. FaktorFaktor yang Berhubungan dengan Perilaku Konsumsi Jajanan pada Pelajar di Sekolah Dasar Negeri 16 dan Sekolah Dasar Negeri 120 Kota Manado. KESMAS. 2019;7(5).

11. Amalia L, Endro OP, Damanik RM. Preferensi dan frekuensi konsumsi makanan jajanan pada anak sekolah dasar di Kecamatan Cijeruk, Kabupaten Bogor. J Gizi dan Pangan [Internet]. 2016 Jun 21 [cited 2020 Sep 28];7(2):119. Available from: https://journal.ipb.ac.id/index. php/jgizipangan/article/view/12374

12. Tampubolon F. Pengaruh Penyuluhan Gizi Dengan Media Visual Poster Dan Leaflet Makanan Sehat Terhadap Perilaku Konsumsi Makanan Jajanan Pelajar Kelas Khusus SMA Negeri 1 Panyabungan Kabupaten Mandailing Natal. Universitas Sumatera Utara; 2010.

13. Noviani K, Afifah E, Astiti D. Kebiasaan jajan dan pola makan serta hubungannya dengan status gizi anak usia sekolah di SD Sonosewu Bantul Yogyakarta. J Gizi dan Diet Indones (Indonesian J Nutr Diet [Internet]. 2016 Aug 30 [cited 2020 Sep 28];4(2):97. Available from: http://dx.doi. org/10.21927/ijnd.2016.4

14. A P, Chaerunimah, R R. Edukasi Gizi Terhadap Pengetahuan Dan Kebiasaan Jajan Pada Siswa SMP Negeri 35 Makassar. Media Gizi Pangan [Internet]. 2018;25(1):77-83. Available from: https://journal.ipb.ac.id/index.php/jgizipangan/ article/view/12374 